\title{
Reese-Ellsworth Classification IVA
}

National Cancer Institute

\section{Source}

National Cancer Institute. Reese-Ellsworth Classification IVA. NCI Thesaurus. Code C123374.

Multiple tumors, some larger than 10 disc diameters. 